\title{
Functional and sensory properties of Indonesian bay leaf (Syzygium polyanthum) herbal tea
}

\author{
*Halim, Y. and Maryani. \\ Food Technology Department, Universitas Pelita Harapan, Jl. M.H. Thamrin Boulevard, Lippo Karawaci, \\ Tangerang 15811, Indonesia
}

\begin{abstract}
Article history:
Received: 12 March 2021

Received in revised form: 21

April 2021

Accepted: 28 June 2021

Available Online: 6 March 2022
\end{abstract}

Keywords:

$\alpha$-glucosidase inhibition

activity,

Antioxidant,

Brewing,

Functional herbal tea,

Syzygium polyanthum

DOI:

https://doi.org/10.26656/fr.2017.6(2).174

\begin{abstract}
Indonesian bay leaf (Syzygium polyanthum) has been reported to contain antioxidants and antidiabetic agents that can bring many health benefits. To increase its consumption, it can be processed into herbal tea with a simple processing method. The objective of this research was to determine the effect of drying temperature, brewing temperature, and brewing time on functional properties and sensory acceptance of Indonesian bay leaf herbal tea. Indonesian bay leaf was dried at three different temperatures $\left(40,50\right.$ and $\left.60^{\circ} \mathrm{C}\right)$ for $24 \mathrm{hrs}$ to increase its shelf life. A drying temperature of $40^{\circ} \mathrm{C}$ was selected for its highest antioxidant properties among the dried Indonesian bay leaf. Indonesian bay leaf herbal tea was prepared with different brewing temperatures $\left(80,90\right.$ and $\left.100^{\circ} \mathrm{C}\right)$ and brewing times $(10,20$ and 30 mins). Results showed that lower brewing temperature $\left(80^{\circ} \mathrm{C}\right)$ and longer brewing time (30 mins) could increase its functional properties, with the highest antioxidant activity $\left(\mathrm{IC}_{50}\right)$ of $984.07 \pm 28.92 \mathrm{ppm}$. Indonesian bay leaf herbal tea brewed for 30 mins showed the highest $\alpha$-glucosidase inhibition activity of $4704.79 \pm 26.31$ ppm, about 85 times weaker compared to acarbose. However, brewing time and temperature did not affect the sensory acceptance of bay leaf herbal tea with an overall hedonic score ranging from 4-5 (slightly like).
\end{abstract}

\section{Introduction}

Indonesian bay leaf (Syzygium polyanthum), also known as "daun salam", is a popular flavouring herb in Indonesia. Different from the true bay leaf or laurel leaf (Laurus nobilis) that is included Lauraceae, Indonesian bay leaf is included in the family of Myrtaceae. The taste of bay leaf is slightly sour or astringent with a weak aroma (Ravindran, 2017). In Indonesia, bay leaf is used as herb incorporated in dishes or as a traditional medicine to cure diarrhoea and stomachache (Jediut et al., 2018). It can also be used to cure gout, stroke, ulcer, gastritis, skin diseases, and stomach inflammation (Harismah dan Chusniatun, 2016; Jediut et al., 2018; Ismail and Ahmad, 2017).

Previous research has reported that Indonesian bay leaf ( $S$. polyanthum) contains several bioactive compounds. Hidayati et al. (2017) reported that methanol extract of the bay leaf could be a great potential source of antioxidants due to high phenolic and flavonoid content. Another study from Widyawati et al. (2015) and Kusuma et al. (2011) also shows that qualitative analysis of bay leaf extract indicated the presence of tannins, glycosides, flavonoids, alkaloids, steroids, triterpenoid, and saponins. Moreover, bay leaf extract can effectively decrease blood glucose with the extent of the hypoglycemic effect is in linear proportion to the dosage, with the most significant dosage of $50 \mathrm{mg} /$ $\mathrm{kg}$ (Wahyuni and Wita, 2017). This result is supported by another study that shows that bay leaf extract exerts an antihyperglycemic effect by inhibiting glucose absorption from the intestine and increasing glucose uptake by muscle in Streptozotocin-induced diabetic rats (Widyawati et al., 2015). However, the utilization of Indonesian bay leaf is still limited in its fresh form (Perdana et al., 2016; Dewijanti et al., 2018), as food flavouring or traditional medicine (Harismah dan Chusniatun, 2016; Abdulrahman et al., 2018). One of the simplest methods to increase bay leaf consumption is by making it into herbal tea.

Herbal tea is made from a variety of plants and leaves other than usual tea plants (Camellia sinensis). It can be brewed from the leaves, flowers, seeds, fruits, stems, and roots of a plant. Herbal tea has been widely used for disease prevention. They are designed for having specific therapeutic or medical benefits (Zhao et 
al., 2013; Ravikumar, 2014). In this research, Indonesian bay leaf was brewed into herbal tea as a more convenient alternative to bay leaf extract because the extraction process is replaced by steeping the tea leaf with hot water. Furthermore, previous treatment, i.e., drying processing of tea leaf enhances the flavour of tea and makes them shelf-stable. This research aimed to determine the effect of drying temperature on antioxidant activity, total phenolic, total flavonoid, and total condensed tannin of the bay leaf and to determine the effect of brewing time and temperature on functional and sensory properties of the Indonesian bay leaf herbal tea.

\section{Materials and methods}

\subsection{Materials and equipment}

The materials used in this research were Indonesian bay leaf Syzygium polyanthum bought from the local market in Tangerang, Indonesia, ethanol 96\%, 1,1,diphenyl-2-picrylhydrazyl (DPPH) solution, $\mathrm{AlCl}_{3}$ $2 \%$, Folin-Ciocalteau reagent, $\mathrm{Na}_{2} \mathrm{CO}_{3}$, quercetin, gallic acid, vanillin, phosphate buffer $(\mathrm{pH}$ 7) containing 200 $\mathrm{mg}$ of Bovine serum albumin, dimethyl sulfoxide (DMSO), methanol purchased from Merck, Jakarta, Indonesia, hydrochloric acid $37 \%$ purchased from SMART-LAB, Tangerang, Indonesia, $\alpha$-glucosidase and $20 \mathrm{mM} p$-nitrophenyl $\alpha$-D-glucopyranoside purchased from Megazyme, Wicklow, Ireland, and distilled water. The equipment used were analytical balance (Ohaus, Germany), chromameter (Konica Minolta, Japan), cuvette, UV-Vis spectrophotometer (DLAB, USA), oven (Memmert UNE800, Germany), pH meter (Ohaus, Germany), water bath (Memmert, Germany), and glassware.

\subsection{Preparation of dried Indonesian bay leaf}

Indonesian bay leaves were sorted and foreign materials were removed. Sorted leaves were then gently rinsed in tap water for cleaning. Cleaned leaves were blanched in hot water at $85^{\circ} \mathrm{C}$ for 2 mins. Cleaned Indonesian bay leaves were spread thinly on aluminium trays and dried in an oven set at the temperature of 40 , 50 , and $60^{\circ} \mathrm{C}$ for about $24 \mathrm{hrs}$ until a moisture content of 5\% (Akila et al., 2018 with modification). Dried Indonesian bay leaves were size reduced for further analysis on moisture content (AOAC, 2005), antioxidant activity using the DPPH method (Elmastaş et al., 2006), total flavonoid (Oktavia, 2011), total condensed tannin (Herald et al., 2014), and total phenolic content (Hartanti et al., 2019). For analysis, $2.5 \mathrm{~g}$ of dried Indonesian bay leaves were submerged in $125 \mathrm{~mL}$ ethanol for $24 \mathrm{hrs}$ for the analysis of antioxidant activity, total flavonoid content, and total condensed tannin. Indonesian bay leaves were steeped in hot demineralized water $\left(100^{\circ} \mathrm{C}\right)$ for 5 mins prior to total phenolic content analysis. The supernatant used in the analysis was obtained by passing the sample solution through Whatman no. 1 filter paper.

\subsection{Determination of the effect of brewing time and temperature on sensory and functional properties of bay leaf herbal tea}

Herbal tea was prepared by brewing dried bay leaves at different times and temperatures. The proportion of tea and water was derived from Franks et al. (2019) with modification. Dried Indonesian bay leaf was weighed about $2.5 \mathrm{~g}$ and added with $125 \mathrm{~mL}$ of hot demineralized water under different temperatures of 80,90 , and $100^{\circ} \mathrm{C}$ for different brewing times $(10,20$, and 30 mins). The tea was cooled under room temperature for approximately $15-17$ mins prior to analysis. Herbal tea from each treatment was analyzed for its antioxidant activity using the DPPH method (Elmastaş et al., 2006), total flavonoid (Oktavia, 2011), total condensed tannin (Herald et al., 2014), total phenolic content (Hartanti et al., 2019), and $\alpha$-glucosidase inhibition activity.

\section{$2.4 \alpha$-glucosidase Inhibition analysis}

$\alpha$-glucosidase inhibition was measured according to the method from Saraswaty (2012) and Wang et al. (2018). The inhibitory activity towards $\alpha$-glucosidase was performed by some preliminary steps: $1 \mathrm{mg}$ of $\alpha$ glucosidase enzyme was firstly diluted in $100 \mathrm{~mL}$ phosphate buffer ( $\mathrm{pH} \mathrm{7)}$ containing $200 \mathrm{mg}$ of bovine serum albumin. While reagent mixtures were prepared as follows: $250 \mu \mathrm{L}$ of $5 \mu \mathrm{mM} \quad p$-nitrophenyl $\alpha$-Dglucopyranoside and $500 \mu \mathrm{L}$ of phosphate buffer mixed with $10 \mu \mathrm{L}$ of sample in DMSO. The reagent mixtures were pre-incubated in a water bath at $37^{\circ} \mathrm{C}$ for 5 mins. The reaction began after the addition of $250 \mu \mathrm{L}$ of enzyme solution prepared in the preliminary steps and continued with incubation for 15 mins. The reaction was terminated by the addition of $1000 \mu \mathrm{L} 200 \mathrm{mM} \mathrm{Na} \mathrm{CO}_{3}$ and the amount of $p$-nitrophenol resulting was measured using a spectrophotometer at $410 \mathrm{~nm}$. There were two controls: negative control was the mixture of reagent without the addition of enzyme solution and acarbose was used as a positive control of $\alpha$-glucosidase inhibitor. Inhibition activity was calculated using the following formula:

$$
\alpha-\text { glucosidase inhibition activity }(\%)=\frac{\mathrm{C}-\mathrm{S}}{\mathrm{C}} \times 100 \%
$$

Where $\mathrm{C}=$ the absorbance of positive control and $\mathrm{S}=$ the absorbance of the sample after reduced by negative control of the sample.

\subsection{Sensory evaluation of Indonesian bay leaf herbal tea}

Sensory evaluation of bay leaf herbal tea was conducted to determine its acceptance by panellists. The 
sensory evaluation was carried out using a 7-scale hedonic test $(1=$ dislike extremely $-7=$ like extremely $)$. The parameters observed by 70 semi-trained panellists were color, aroma, astringency, taste, aftertaste, and overall acceptance (Stone et al., 2012).

\subsection{Data analysis}

All data obtained in this research were analyzed statistically using Univariate Analysis and Post Hoc Test using Duncan. The software used was SPSS version 22.

\section{Results and discussion}

3.1 Effect of drying temperature on Indonesian bay leaf functional properties

Drying was performed in this research since in tea manufacturing, one of the important stages is drying to remove moisture and increase the shelf life (Chong and $\mathrm{Lim}, 2012$ ). The moisture content of $10 \%$ to $11 \%$ may lead to spoilage (Lund et al., 2000). Results showed that drying at 40,50 , and $60^{\circ} \mathrm{C}$ for $24 \mathrm{hrs}$ could reduce Indonesian bay leaf moisture content (\%wb) to less than $5 \%$, i.e., $4.46 \pm 0.05 \%, 4.40 \pm 0.13 \%$, and $4.37 \pm 0.08 \%$, respectively, making it more shelf-stable during storage.

To determine the effect of drying temperature on functional properties of Indonesian bay leaf, several analyses were done, and the result can be observed in Table 1. Antioxidant activity of Indonesian bay leaf was expressed as $\mathrm{IC}_{50}$ value on a dry basis. The statistical analysis of the antioxidant activity showed that there was a significant effect $(\mathrm{p} \leq 0.05)$ of the drying temperature on the antioxidant activity. Indonesian bay leaf dried under $40^{\circ} \mathrm{C}\left(\mathrm{IC}_{50}=477.87 \pm 5.97 \mathrm{ppm}\right)$ displayed the highest antioxidant activity and significantly different than Indonesian bay leaf dried under $50^{\circ} \mathrm{C}$ and $60^{\circ} \mathrm{C}$. This suggests that temperature affects the antioxidant activity through the initiation of some chemical reactions that might cause oxidative damages (Thamer et al., 2018).

The fresh Indonesian bay leaf $\left(\mathrm{IC}_{50}=130.50 \pm 1.32\right.$ ppm) exerts a higher antioxidant activity compared to those dried Indonesian bay leaf as Indonesian bay leaf dried under 40,50 and $60^{\circ} \mathrm{C}$ that $\mathrm{IC}_{50}$ values of more than $500 \mathrm{ppm}$ which was considered low. This result showed that the drying process on Indonesian bay leaf displayed a relatively weak antioxidant activity due to the reduction of antioxidants. According to Ahmad et al. (2015), antioxidant capacity with an $\mathrm{IC}_{50}$ value above $150 \mathrm{ppm}$ is considered weak. A previous study on the antioxidant activity of the dried Indonesian bay leaf methanolic extract showed an antioxidant activity with the $\mathrm{IC}_{50}$ of $90.85 \mu \mathrm{g} / \mathrm{mL}$ (Har and Intan, 2012). However, $\mathrm{IC}_{50}$ of Indonesian bay leaf dried at $40^{\circ} \mathrm{C}$ is also comparable to $\mathrm{IC}_{50}$ of fenugreek methanolic extract $(444.1 \pm 5.5 \mathrm{ppm})$, lower than cardamom methanolic extract (681.5 $\pm 8.4 \mathrm{ppm}$ ) (Khalaf et al., 2008), and lower than Roselle leaves that were oven-dried at $60^{\circ} \mathrm{C}(2.2$ $\mathrm{mg} / \mathrm{mL}$ or $2200 \mathrm{ppm}$ ). This means that the antioxidant activity of bay leaf is higher compared to cardamom or fenugreek extract and dried Roselle leaves. However, green tea leaves that were oven-dried at $60^{\circ} \mathrm{C}$ has lower $\mathrm{IC}_{50}$, i.e., $167.166 \mathrm{ppm}$ (Roshanak et al., 2016) compared to dried Indonesian bay leaf.

The increase of drying temperature could also cause the reduction of antioxidant capacity as high drying temperature may lead to the depletion of phenolics, flavonoids and tannins (Thamer et al., 2018). It is also expressed in the results shown in Table 1, that higher drying temperature significantly decreases the total phenolics, flavonoid, and condensed tannin of Indonesian bay leaf. Dried Indonesian bay leaf under $40^{\circ}$ C (7.33 $\pm 0.54 \mathrm{mg}$ GAE/g sample) had the highest phenolic content compared Indonesian bay leaf dried at $50^{\circ} \mathrm{C}$ and $60^{\circ} \mathrm{C}$. Furthermore, Indonesian bay leaf dried under different temperatures $\left(40,50\right.$, and $\left.60^{\circ} \mathrm{C}\right)$ displayed total phenolic content that was slightly lower than fresh Indonesian bay leaf $(10.76 \pm 1.50 \mathrm{mg}$ GAE/g sample). This can happen because phenolic compounds are also very sensitive to high temperatures or the presence of oxygen (Nguyen and Chuyen, 2020).

Furthermore, dried Indonesian bay leaf with $40^{\circ} \mathrm{C}$ drying temperature $(18.94 \pm 2.49 \mathrm{mg} \mathrm{QE} / \mathrm{g}$ sample) had the highest flavonoid content compared to the other dried Indonesian bay leaf, although it was not significantly different from Indonesian bay leaf dried at $50^{\circ} \mathrm{C}$ $(16.60 \pm 2.20 \mathrm{mg} \mathrm{QE} / \mathrm{g}$ sample) and Indonesian bay leaf dried at $60^{\circ} \mathrm{C}(15.09 \pm 2.35 \mathrm{mg} \mathrm{QE} / \mathrm{g}$ sample), regardless the high flavonoid content of fresh bay leaf $(67.97 \pm 6.32$ $\mathrm{mg}$ QE/g sample). According to Sukmasari et al. (2018),

Table 1. Functional properties of Indonesian bay leaf at different drying temperatures

\begin{tabular}{lcccc}
\hline \multicolumn{1}{c}{ Treatment } & $\begin{array}{c}\text { Antioxidant activity } \\
(\mathrm{ppm})\end{array}$ & $\begin{array}{c}\text { Total phenolic content } \\
(\mathrm{mg} \text { GAE/g leaf db })\end{array}$ & $\begin{array}{c}\text { Total condensed tannin } \\
(\mathrm{mg} \text { CE/g leaf db })\end{array}$ & $\begin{array}{c}\text { Total flavonoid content } \\
(\mathrm{mg} \text { QE/g leaf db })\end{array}$ \\
\hline Fresh Indonesian Bay leaf & $130.50 \pm 1.32^{\mathrm{a}}$ & $10.76 \pm 1.50^{\mathrm{c}}$ & $110.80 \pm 1.88^{\mathrm{a}}$ & $67.97 \pm 6.32^{\mathrm{b}}$ \\
Dried Indonesian Bay leaf $\left(40^{\circ} \mathrm{C}\right)$ & $477.87 \pm 5.97^{\mathrm{b}}$ & $7.33 \pm 0.54^{\mathrm{b}}$ & $29.85 \pm 0.74^{\mathrm{b}}$ & $18.94 \pm 2.49^{\mathrm{a}}$ \\
Dried Indonesian Bay leaf $\left(50^{\circ} \mathrm{C}\right)$ & $576.53 \pm 8.69^{\mathrm{c}}$ & $6.41 \pm 0.82^{\mathrm{ab}}$ & $26.48 \pm 0.77^{\mathrm{c}}$ & $16.60 \pm 2.20^{\mathrm{a}}$ \\
Dried Indonesian Bay leaf $\left(60^{\circ} \mathrm{C}\right)$ & $624.22 \pm 5.19^{\mathrm{d}}$ & $5.35 \pm 0.76^{\mathrm{a}}$ & $20.37 \pm 0.34^{\mathrm{d}}$ & $15.09 \pm 2.35^{\mathrm{a}}$ \\
\hline
\end{tabular}

Values are presented as mean \pm SD. Values with different superscript within the same column are significantly different ( $\mathrm{p} \leq 0.05$ ). $\mathrm{db}$, dry basis. 
flavonoid content was not necessarily linked to total phenolic content depending on the types of solvents used for making extracts. The extract of Syzygium cumini using ethyl acetate and acetone showed a high total flavonoid and low total phenolic content. Therefore, a sample with low phenolic content might have high flavonoid content depending on the solubility of the compounds in the solvents. In this research, dried leaves were submerged in hot water for phenolic analysis, whereas for other analyses, the leaves were submerged in ethanol.

Total condensed tannin plays a determinant role in the quality of plants as it was much more resistant to microbial degradation than hydrolysable tannin and it exhibited a stronger antioxidant activity and $\alpha$ glucosidase inhibition activity than hydrolysable tannin (Ashok and Upadhyaya, 2012). Based on the statistical analysis, there was a significant effect $(\mathrm{p} \leq 0.05)$ of drying temperature on total condensed tannin. The condensed tannin of Indonesian bay leaf dried at $40^{\circ} \mathrm{C}, 50^{\circ} \mathrm{C}$, and $60^{\circ} \mathrm{C}$ was significantly lower than fresh Indonesian bay leaf. A reduction in condensed tannins along with the increase of temperature was coherent with the results from a study conducted by Palmer et al. (2000) who found higher amounts of condensed tannins in freezedried samples than oven-dried samples. Tannins are compounds naturally present in plant tissue that have been known to give many beneficial health effects, such as antiviral and antimicrobial. However, tannins also cause astringent and unpleasant taste, such as the dry and puckery feeling in the mouth (Ashok and Upadhyaya, 2012). Moreover, a lower amount of condensed tannin in dried Indonesian bay leaf compared to dried soursop leaves brew (181.32 $\pm 31.62 \mathrm{ppm})$ (Hardoko et al., 2018) indicates that Indonesian bay leaf herbal tea could offer better sensory acceptability compared to soursop leaves brew. Even though dried Indonesian bay leaf had lower antioxidant activity compared to its fresh form, it offers longer shelf life as the moisture content is reduced significantly. Based on this consideration, a further experiment was done using Indonesian bay leaf dried at $40^{\circ} \mathrm{C}$.

\subsection{Effect of brewing time and temperature on antioxidant activity of bay leaf herbal tea}

The statistical analysis on antioxidant activity showed that brewing time and brewing temperature significantly affect $(\mathrm{p} \leq 0.05)$ the antioxidant capacity of Indonesian bay leaf herbal tea. There was also a significant interaction between the brewing temperature and brewing time of Indonesian bay leaf herbal tea. Results of statistical analysis can be observed in Figure 1. Figure 1 shows that Indonesian bay leaf brewed at $80^{\circ} \mathrm{C}$ for 30 mins displayed the highest antioxidant activity ( $\mathrm{IC}_{50}$ of $\left.954.15 \pm 10.01 \mathrm{ppm}\right)$, whereas the highest brewing temperature $\left(100^{\circ} \mathrm{C}\right)$ for shortest time (10 mins) displayed the lowest antioxidant activity $\left(\mathrm{IC}_{50}\right.$ of $1759.91 \pm 50.11 \mathrm{ppm})$.

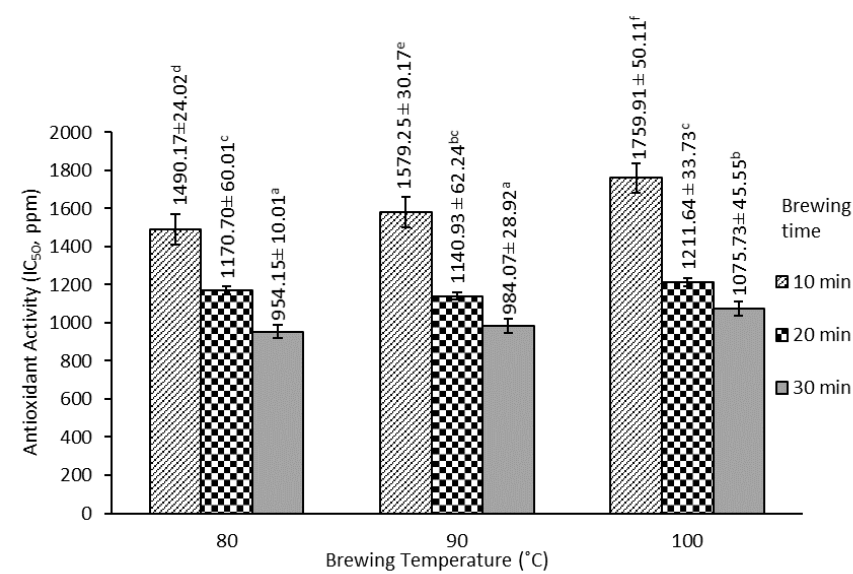

Figure 1. Effect of brewing temperature and time on antioxidant activity $\left(\mathrm{IC}_{50}\right)$ of Indonesian bay leaf herbal tea. Values above bars are presented as mean \pm SD. Values with different superscripts are significantly different $(p \leq 0.05)$.

Higher temperature reduced the antioxidant capacity, however, longer brewing time enhanced the antioxidant capacity of the bay leaf herbal tea. The longer brewing time of bay leaf herbal tea promoted the release of phenolic compounds, flavonoids, and tannins into the tea. The antioxidant capacity was reduced with the increase of brewing temperature. This might be due to the degradation of phenolic and flavonoids content in higher temperatures (Hajiaghaalipour et al., 2016). Antioxidant activity of Indonesian bay leaf herbal tea brewed at $80^{\circ} \mathrm{C}$ for 30 mins is higher compared to Cheeseweed (Malva parviflora L.) leaves and stems infused in water at $60^{\circ} \mathrm{C}$ for $24 \mathrm{hrs}$, with $\mathrm{IC}_{50}$ value of 1.5 $\mathrm{mg} / \mathrm{mL}$ (or $1500 \mathrm{ppm}$ ) and $1.8 \mathrm{mg} / \mathrm{mL}$ (or $1800 \mathrm{ppm}$ ), respectively (Farhan et al., 2012) and some plant aqueous extract ( $30 \mathrm{~g}$ powder in $150 \mathrm{~mL}$ water) prepared at $100^{\circ} \mathrm{C}$ for $10 \mathrm{~min}$, i.e. Indian bay leaf (Cinnamomum tamala) with $\mathrm{IC}_{50}$ of $6.9 \pm 0.05 \mathrm{mg} / \mathrm{g}$ (or about $6900 \mathrm{ppm}$ ), coriander seeds (Coriandrum sativum) with $\mathrm{IC}_{50}$ of $2.86 \pm 0.07 \mathrm{mg} / \mathrm{g}$ (or about $2860 \mathrm{ppm}$ ), and cardamom seeds (Ellettaria cardamomum) aqueous extract with $\mathrm{IC}_{50}$ of $61.75 \pm 3.03 \mathrm{mg} / \mathrm{g}$ (or about $61750 \mathrm{ppm}$ ) (Deepa et al., 2013). However, the antioxidant activity of Indonesian bay leaf herbal tea in this research is also lower compared to other herbal infusions from Lamiaceae family, such as infusion of peppermint $\left(\mathrm{IC}_{50}\right.$ $=35.75 \mathrm{ppm})$, basil $\left(\mathrm{IC}_{50}=26.37 \mathrm{ppm}\right)$, and thyme $\left(\mathrm{IC}_{50}\right.$ $=39.20 \mathrm{ppm})$ (Albayrak et al., 2013).

In terms of total phenolic, total flavonoid, and total condensed tannin, statistical results using Univariate showed that interaction between the brewing temperature and the brewing time of the bay leaf herbal tea did not significantly affect $(p>0.05)$ those parameters. However, 
Table 2. Effect of brewing temperature on total phenolic, total flavonoid, and total condensed tannin content

\begin{tabular}{cccc}
\hline Brewing temperature $\left({ }^{\circ} \mathrm{C}\right)$ & $\begin{array}{c}\text { Total phenolic content } \\
(\mathrm{mg} \mathrm{GAE} / \mathrm{g} \text { leaf db })\end{array}$ & $\begin{array}{c}\text { Total flavonoid content } \\
(\mathrm{mg} \mathrm{QE} / \mathrm{g} \text { leaf db })\end{array}$ & $\begin{array}{c}\text { Total condensed tannin } \\
(\mathrm{mg} \mathrm{CE} / \mathrm{g} \text { leaf db })\end{array}$ \\
\hline 80 & $0.95 \pm 0.37^{\mathrm{a}}$ & $0.22 \pm 0.05^{\mathrm{a}}$ & $8.69 \pm 1.79^{\mathrm{a}}$ \\
90 & $0.80 \pm 0.39^{\mathrm{ab}}$ & $0.19 \pm 0.03^{\mathrm{b}}$ & $8.45 \pm 1.61^{\mathrm{b}}$ \\
100 & $0.56 \pm 0.29^{\mathrm{b}}$ & $0.16 \pm 0.04^{\mathrm{c}}$ & $8.03 \pm 1.58^{\mathrm{c}}$ \\
\hline
\end{tabular}

Values are presented as mean \pm SD. Values with different superscript within the same column are significantly different ( $\mathrm{p} \leq 0.05$ ). $\mathrm{db}$, dry basis.

Table 3. Effect of brewing time on total phenolic, total flavonoid, and total condensed tannin content

\begin{tabular}{cccc}
\hline Brewing temperature $\left({ }^{\circ} \mathrm{C}\right)$ & $\begin{array}{c}\text { Total phenolic content } \\
(\mathrm{mg} \mathrm{GAE} / \mathrm{g} \text { leaf db })\end{array}$ & $\begin{array}{c}\text { Total flavonoid content } \\
(\mathrm{mg} \mathrm{QE} / \mathrm{g} \text { leaf db })\end{array}$ & $\begin{array}{c}\text { Total condensed tannin } \\
(\mathrm{mg} \mathrm{CE} / \mathrm{g} \mathrm{leaf} \mathrm{db})\end{array}$ \\
\hline 10 & $0.48 \pm 0.17^{\mathrm{a}}$ & $0.15 \pm 0.03^{\mathrm{a}}$ & $6.49 \pm 0.28^{\mathrm{a}}$ \\
20 & $0.75 \pm 0.30^{\mathrm{b}}$ & $0.19 \pm 0.05^{\mathrm{b}}$ & $8.36 \pm 0.32^{\mathrm{b}}$ \\
30 & $1.08 \pm 0.35^{\mathrm{c}}$ & $0.23 \pm 0.03^{\mathrm{c}}$ & $10.31 \pm 0.43^{\mathrm{c}}$ \\
\hline
\end{tabular}

Values are presented as mean \pm SD. Values with different superscript within the same column are significantly different ( $\mathrm{p} \leq 0.05$ ). $\mathrm{db}$, dry basis.

both brewing temperature and brewing time significantly affect $(\mathrm{p} \leq 0.05)$ the total phenolic content, total flavonoid, and total condensed tannin of Indonesian bay leaf herbal tea. These results can be further observed in Table 2 and Table 3.

Results showed the similar pattern to antioxidant activity results, in which Indonesia bay leaf herbal tea brewed at $80^{\circ} \mathrm{C}$ had the highest phenolic content, flavonoid content, and total condensed tannin, i.e., $0.95 \pm 0.37 \mathrm{mg}$ GAE $/ \mathrm{g}$ sample, $0.22 \pm 0.05 \mathrm{mg} \mathrm{QE} / \mathrm{g}$ sample, and $8.69 \pm 1.79 \mathrm{mg} \mathrm{CE} / \mathrm{g}$ sample, respectively. This can be explained as phenolic compounds mainly contribute to antioxidant activity (Wojdyło et al., 2007). This result is contrary to previous research, which stated that green tea, corn silk, senna, and rosemary brewed at $100^{\circ} \mathrm{C}$ had a higher amount of phenolic, flavonoid, and condensed tannin compared to those brewed at $60^{\circ} \mathrm{C}$ and $80^{\circ} \mathrm{C}$ (Kiliç et al., 2017). Moreover, tea brewed for a long time had a greater quantity of phenolic compounds, flavonoid compounds, and condensed tannin. The brewing time and temperature had been reported to be the most critical factors that affect total phenolic content and antioxidant activity. Increasing water temperature for brewing increases total phenolic content to a certain level and then decreased afterwards, while the solubility of phenolic compounds increased with an increase in time until it reaches the maximum level (İlyasoğlu and Arpa, 2017). Longer brewing time has also been reported to increase the total phenolic content of Roselle herbal tea (Nguyen and Chuyen, 2020).

In terms of total phenolic content, Indonesian bay leaf herbal tea contains a much lower amount of phenolic compounds compared to green tea, black tea, and chamomile infusions, i.e. $150 \pm 27.7 \mathrm{mg} \mathrm{GAE} / \mathrm{g}$, $130 \pm 18.2 \mathrm{mg} \mathrm{GAE} / \mathrm{g}$, and $44 \pm 7.9 \mathrm{mg}$ GAE $/ \mathrm{g}$, respectively (Rusaczonek et al., 2010). It is also lower compared to coriander seeds aqueous extract, i.e., $3.14 \pm 0.12 \mathrm{mg} \mathrm{GAE} / \mathrm{g}$, but higher compared to cardamom and Indian bay leaf aqueous extract, i.e., $0.55 \pm 0.08 \mathrm{mg}$ GAE/g and $0.16 \pm 0.05 \mathrm{mg} \mathrm{GAE} / \mathrm{g}$, respectively (Deepa et al., 2013). These results show that phenolic compounds extracted from brewing could be various depending on the type and part of a plant used.

Similar to total phenolic content and total flavonoid content, higher brewing temperature decreased the quantity of condensed tannin regardless of the effect of brewing time. The reduction of total condensed tannins was reduced due to the increased brewing temperature that caused the destruction of condensed tannin, while longer brewing time allowed the leaching of condensed tannins (Krzyzowska et al., 2017). The tannin content of bay leaf herbal tea is considered to be low in comparison to black tea brewed at $90^{\circ} \mathrm{C}$ for 3 mins $(76.8 \mathrm{mg} / \mathrm{g})$ (Negukhula, 2010), but higher compared to coriander seeds, cardamom, and Indian bay leaf aqueous extract, which have total tannin content of $1.4 \pm 0.03 \mathrm{mg} \mathrm{CE} / \mathrm{g}$, $0.22 \pm 0.07 \mathrm{mg} \mathrm{CE} / \mathrm{g}$, and $1.4 \pm 0.07 \mathrm{mg} \mathrm{CE} / \mathrm{g}$, respectively (Deepa et al., 2013).

\subsection{Effect of brewing time and temperature on $\alpha$ - glucosidase inhibition activity of bay leaf herbal tea}

The effectiveness of bay leaf decoction ( $S$. polyanthum) or extract (Laura nobilis) as an antidiabetic agent in reducing blood glucose had been reported from previous research (Dewijanti et al., 2018; Al Chalabi et al., 2020). However, the experiment on its $\alpha$-glucosidase inhibition activity of bay leaf herbal tea under different brewing time and temperature have not been studied. $\alpha$ glucosidase inhibitors are important to regulate postprandial hyperglycemia (PPHG) in diabetic patients. Moreover, inhibition of this enzyme could reduce starch digestion and slow down the increase of blood glucose content (Ahamad et al., 2011; Xu et al., 2019). 
Statistical analysis of the $\alpha$-glucosidase inhibition activity showed that there was no significant interaction ( $p>0.05$ ) between the brewing temperature and brewing time of Indonesian bay leaf herbal tea. The brewing temperature did not give a significant effect $(\mathrm{p}>0.05)$ on the inhibition activity towards $\alpha$-glucosidase, while brewing time significantly affect $(\mathrm{p} \leq 0.05) \alpha$-glucosidase inhibition activity of Indonesian bay leaf herbal tea. These results can be seen in Table 4. This means that regardless of the temperature used for brewing, longer brewing time yielded greater antidiabetic properties. Herbal tea brewed for $30 \mathrm{mins}$ had the highest $\alpha$ glucosidase inhibition activity $\left(\mathrm{IC}_{50}\right)$, i.e., $4704.79 \pm 26.31$ ppm. Meanwhile, $\mathrm{IC}_{50}$ of acarbose as a positive control was $56.60 \pm 0.46 \mathrm{ppm}$. This result shows that Indonesian bay leaf herbal tea was about 85 times weaker inhibition activity towards $\alpha$-glucosidase compared to acarbose. It is also lower compared to crude water extract of Qingzhuan dark tea $\left(\mathrm{IC}_{50}=2.47 \pm 0.30 \mathrm{mg} / \mathrm{mL}\right.$ or about $2470 \mathrm{ppm}$ ) (Liu et al., 2016), slightly lower than green tea infusion $\left(\mathrm{IC}_{50}=3.91 \mathrm{mg} / \mathrm{mL}\right.$ or about $3910 \mathrm{ppm}$ ) (Rodrigues et al., 2019) but higher when compared to another beverage, such as sappanwood (Caesalpinia sappan L.) and lemongrass extract (Cymbopogon citratus) beverage $\left(\mathrm{IC}_{50}=10932.50 \pm 273.25 \mathrm{ppm}\right)$ (Siregar and Verena, 2019).

Table 4. Effect of brewing time on $\alpha$-glucosidase inhibition activity

\begin{tabular}{cc}
\hline $\begin{array}{c}\text { Brewing time } \\
(\min )\end{array}$ & $\alpha$-glucosidase inhibition activity \\
$(\mathrm{ppm})$
\end{tabular}

Values with different superscripts are significantly different $(p \leq 0.05)$. Data was obtained from average of $\alpha$-glucosidase inhibition activity at different brewing temperature.

$\alpha$-glucosidase inhibition activity of the plant is related to its antioxidant activity and phytochemical compounds. Phytochemical compounds in a plant show a positive correlation with antioxidant and $\alpha$-glucosidase inhibitory activity (Chen et al., 2019). Furthermore, tannin content and flavonoid content in tea leaf were the main potential indicators of medical usage. The presence of both condensed tannin and flavonoid contributed to a reduction of blood glucose levels due to its antioxidant constituent (Kunyanga et al., 2011 and Castiglioni et al., 2015). $\alpha$-glucosidase inhibition activity of White tea was also found to be strongly correlated with its phenolic content (Xu et al., 2019). Therefore, relatively low total condensed tannin content and total flavonoid content observed in Indonesian bay leaf herbal tea might contribute to a relatively weak $\alpha$-glucosidase inhibition.

\subsection{Effect of brewing time and temperature on sensory properties of bay leaf herbal tea}

Sensory evaluation was done to determine the acceptance of Indonesian bay leaf herbal tea prepared with different brewing temperatures and times. It is because bay leaf contains tannins, which contributes to astringency and puckering sensation in the mouth when consumed (Ashok and Upadhyaya, 2012). Based on the statistical analysis, there was no significant effect $(p>0.05)$ of brewing temperature and brewing time on the preference of panellists to the samples. Table 5 shows the results of a hedonic test on the color, aroma, astringency, taste, aftertaste, and overall acceptance of Indonesian bay leaf herbal tea. The hedonic score for all parameters observed on Indonesian bay leaf herbal tea brewed at different temperatures and times were in the range of 4.5 to 5 , which means that Indonesian bay leaf herbal tea was acceptable and slightly liked by the panellists. It also means that relatively low tannin, flavonoid, and phenolic content contributes to a more acceptable astringency and bitter aftertaste in Indonesian bay leaf herbal tea.

\section{Conclusion}

Indonesian bay leaf herbal tea could be beneficial for health as it contains antioxidants and antidiabetic properties. However, the drying and brewing process at higher temperatures affect the antioxidant capacity, total phenolic content, total flavonoid content, total condensed tannin content, and $\alpha$-glucosidase inhibition activity. The best drying temperature in the making of dried

Table 5. Sensory (hedonic) results of Indonesian bay leaf herbal tea

\begin{tabular}{cccccccc}
\hline Brewing temperature $\left({ }^{\circ} \mathrm{C}\right)$ & Brewing time $(\mathrm{min})$ & Color & Aroma & Astringency & Taste & Aftertaste & Overall \\
\hline 80 & 10 & $4.5 \pm 1.1$ & $4.6 \pm 1.2$ & $4.52 \pm 1.32$ & $4.54 \pm 1.22$ & $4.66 \pm 1.15$ & $4.67 \pm 1.25$ \\
80 & 20 & $4.7 \pm 1.1$ & $4.5 \pm 1.1$ & $4.57 \pm 1.11$ & $4.53 \pm 1.35$ & $4.56 \pm 1.22$ & $4.74 \pm 1.09$ \\
80 & 30 & $4.7 \pm 1.1$ & $4.6 \pm 1.2$ & $4.47 \pm 1.33$ & $4.51 \pm 1.39$ & $4.60 \pm 1.27$ & $4.77 \pm 1.21$ \\
90 & 10 & $4.5 \pm 1.0$ & $4.6 \pm 1.1$ & $4.61 \pm 1.20$ & $4.56 \pm 1.42$ & $4.66 \pm 1.20$ & $4.67 \pm 1.39$ \\
90 & 20 & $4.8 \pm 1.0$ & $4.7 \pm 1.2$ & $4.27 \pm 1.24$ & $4.47 \pm 1.28$ & $4.56 \pm 1.19$ & $4.67 \pm 1.16$ \\
90 & 30 & $4.6 \pm 1.0$ & $4.5 \pm 1.3$ & $4.37 \pm 1.26$ & $4.29 \pm 1.31$ & $4.30 \pm 1.31$ & $4.59 \pm 1.19$ \\
100 & 10 & $4.6 \pm 1.1$ & $4.6 \pm 1.3$ & $4.37 \pm 1.24$ & $4.57 \pm 1.33$ & $4.44 \pm 1.22$ & $4.76 \pm 1.13$ \\
100 & 20 & $4.8 \pm 1.1$ & $4.6 \pm 1.2$ & $4.37 \pm 1.22$ & $4.41 \pm 1.28$ & $4.27 \pm 1.32$ & $4.59 \pm 1.19$ \\
100 & 30 & $4.9 \pm 1.0$ & $4.6 \pm 1.2$ & $3.46 \pm 1.13$ & $4.41 \pm 1.34$ & $4.51 \pm 1.20$ & $4.64 \pm 1.23$ \\
\hline
\end{tabular}


Indonesian bay leaf was $40^{\circ} \mathrm{C}$, which produced the highest antioxidant activity, total phenolic content, total flavonoid content, and total condensed tannin. Lower brewing temperature and longer brewing time affected increased the functional properties of Indonesian bay leaf herbal tea. Brewing at $80^{\circ} \mathrm{C}$ for 30 mins resulted in the highest antioxidant activity. $\alpha$-glucosidase inhibition activity of herbal tea was 85 times weaker compared to acarbose with the best $\mathrm{IC}_{50}$ value was found at $30 \mathrm{mins}$ brewing time. The hedonic sensory test showed that most panellists slightly liked the brewed bay leaf herbal tea despite the different brewing times and temperatures. This indicates a possibility for the commercialization of Indonesian bay leaf as functional herbal tea.

\section{Conflict of Interest}

The authors declare no conflict of interest.

\section{References}

Abdulrahman, M.D., Ali, A.M., Fatihah, H.N., Khandaker, M.M. and Mat, N. (2018). Morphological and anatomical studies of Syzygium polyanthum (Wight) Walp. (Myrtaceae). Malayan Nature Journal, 70(3), 309-322.

Ahamad, J., Naquvi, K.J., Mir, S.R., Ali, M. and Shuaib, M. (2011). Review on role of natural alphaglucosidase inhibitors for management of diabetes mellitus. International Journal of Biomedical Research, 2(6), 374-380. https://doi.org/10.7439/ ijbr.v2i6.121

Ahmad, I., Sulistiarini, R. and Rijai, L. (2015). Antioxidant activity of some selected East Borneo plants. International Journal of Health and Pharmaceutical Sciences, 4(1), 58-62. https:// doi.org/10.11591/ijphs.v4i1.4712

Akila, B., Vijayalakshmi, R., Hemalatha, G. and Arunkumar, R. (2018). Development and evaluation of functional property of guava leaf based herbal tea. Journal of Pharmacognosy and Phytochemistry, 7 (3), 3036-3039.

Al Chalabi, S.M.M., Majeed, D.M., Jasim, A.A. and AlAzzawi, K.S. (2020). Benefit effect of ethanolic extract of Bay leaves (Laura nobilis) on blood sugar level in adult diabetic rats induced by alloxan monohydrate. Annals of Tropical Medicine and Public Health, 23(16). https://doi.org/10.36295/ ASRO.2020.231608

Albayrak, S., Aksoy, A., Albayrak, S. and Sagdic, O. (2011). In vitro antioxidant and antimicrobial activity of some Lamiaceae species. Iranian Journal of Science and Technology, 37(1), 1-9.

AOAC. (2005). Official methods of analysis of AOAC
International. 18th ed. Gaithersburg, USA: AOAC International.

Ashok, P.K. and Upadhyaya, K. (2012). Tannins are astringent. Journal of Pharmacognosy and Phytochemistry, 1(3), 45-50.

Castiglioni, S., Damiani, E., Astolfi, P. and Carloni, P. (2015). Influence of steeping conditions (time, temperature, and particle size) on antioxidant properties and sensory attributes of some white and green teas. International journal of food sciences and nutrition, 66(5), 491-497. https:// doi.org/10.3109/09637486.2015.1042842

Chen, Y., Wang, E., Wei, Z., Zheng, Y., Yan, R. and Ma, X. (2019). Phytochemical analysis, cellular antioxidant and $\alpha$-glucosidase inhibitory activities of various herb plant organs. Industrial Crops and Products, 141, 111171. https://doi.org/10.1016/ j.indcrop.2019.111771

Chong, K.L. and Lim, Y.Y. (2012). Effect of drying on the antioxidant properties of herbal tea from selected Vitex species. Journal of Food Quality, 35(1), 51-59. https://doi.org/10.1111/j.1745-4557.2011.00422.x

Deepa, G., Ayesha, S., Nishtha, K. and Thankamani, M. (2013). Comparative evaluation of various total antioxidant capacity assays applied to phytochemical compounds of Indian culinary spices. International Food Research Journal, 20(4), 1711-1716.

Elmastaş, M., Gülçin, İ., Işildak, Ö., Küfrevioğlu, Ö.İ., İbaoğlu, K. and Aboul-Enein, H.Y. (2006). Radical scavenging activity and antioxidant capacity of bay leaf extracts. Journal of the Iranian Chemical Society, 3(3), 258-266. https://doi.org/10.1007/ BF03247217

Farhan, H., Rammal, H., Hijazi, A., Hamad, H., Daher, A., Reda, M. and Badran, B. (2012). In vitro antioxidant activity of ethanolic and aqueous extracts from crude Malva parviflora L. grown in Lebanon. Asian Journal of Pharmaceutical and Clinical Research, 5(3), 234-238.

Franks, M., Lawrence, P., Abbaspourrad, A. and Dando, R. (2019). The influence of water composition on flavor and nutrient extraction in green and black tea. Nutrients, 11(1), $80 . \quad$ https://doi.org/10.3390/ nu11010080

Hajiaghaalipour, F., Sanusi, J. and Kanthimathi, M.S. (2016). Temperature and time of steeping affect the antioxidant properties of white, green, and black tea infusions. Journal of Food Science, 81(1), 246-254. https://doi.org/10.1111/1750-3841.13149

Har, L. and Intan, S.I. (2012). Antioxidant activity, total phenolics and total flavonoids of Syzygium polyanthum (Wight) Walp leaves. International 
Journal of Medicinal and Aromatic Plants, 2(2), 219 -228 .

Hardoko, Tanudjaja, Y., Mastuti, T.S. and Halim, Y. (2018). Utilization of soursop leaves as antihyperuricemic in functional beverage 'herbal green tea'. International Food Research Journal, 25 (1), 321-328.

Harismah, K. and Chusniatun. (2016). Pemanfaatan daun salam (Eugenia polyantha) sebagai obat herbal dan rempah penyedap makanan. Warta LPM, 19(2), 110118. https://doi.org/10.23917/warta.v19i2.2742 [In Bahasa Indonesia].

Hartanti, L., Yonas, S.M.K., Mustamu, J.J., Wijaya, S., Setiawan, H.K. and Soegianto, L. (2019). Influence of extraction methods of bay leaves (Syzygium polyanthum) on antioxidant and HMG-CoA Reductase inhibitory activity. Heliyon, 5(4), 1485. https://doi.org/10.1016/j.heliyon.2019.e01485

Herald, T.J., Gadgil, P., Perumal, R., Bean, S.R. and Wilson, J.D. (2014). High-throughput micro-plate $\mathrm{HCl}-$ vanillin assay for screening tannin content in sorghum grain. Journal of the Science of Food and Agriculture, 94(10), 2133-2136. https:// doi.org/10.1002/jsfa.6538

Hidayati, M.D., Ersam, T., Shimizu, K. and Fatmawati, S. (2017). Antioxidant activity of Syzygium polyanthum extracts. Indonesian Journal of Chemistry, 17(1), 49-53. https://doi.org/10.22146/ ijc. 23545

İlyasoğlu, H. and Arpa, T.E. (2017). Effect of brewing conditions on antioxidant properties of rosehip tea beverage: study by response surface methodology. Journal of Food Science and Technology, 54(11), 3737-3743. https://doi.org/10.1007/s13197-017-2794 $-2$

Ismail, A. and Ahmad, W. (2017). Autonomic receptors and nitric-oxide involvements in mediating vasorelaxation effect induced by Syzygium polyanthum leaves extract. Pharmacognosy Research, 9(5), 9-14. https://doi.org/10.4103/ pr.pr_69_17

Jediut, M., Utama, W.G. and Madu, F.J. (2018). Pembuatan teh herbal daun salam sebagai minuman alternatif pada peserta posyandu Dusun Akel dan Dusun Cipi kecamatan Cibal Barat. Jurnal Inovasi Pendidikan Dasar, 2(2), 169-174. [In Bahasa Indonesia].

Khalaf, N.A., Shakya, A.K., Al-Othman, A., El-Agbar, A. and Farah, H. (2008). Antioxidant activity of some common plants. Turkish Journal of Biology, $32,51-55$.

Kiliç, C., Can, Z., Yilmaz, A., Yildiz, S. and Turna, H.
(2017). Antioxidant properties of some herbal teas (green tea, senna, corn silk, rosemary) brewed at different temperatures. International Journal of Secondary Metabolite, 4(3), 142-148. https:// doi.org/10.21448/ijsm.369273

Krzyzowska, M., Tomaszewska, E., Ranoszek-Soliwoda, K., Bien, K., Orlowski, P., Celichowski, G. and Grobelny, J. (2017). Tannic acid modification of metal nanoparticles: possibility for new antiviral applications. In Grumezescu, A.M. and Andronescu, E. (Eds). Nanostructures for Oral Medicine, p. 335363. Oxford, United Kingdom: Elsevier. https:// doi.org/10.1016/B978-0-323-47720-8.00013-4

Kunyanga, C.N., Imungi, J.K., Okoth, M., Momanyi, C., Biesalski, H.K. and Vadivel, V. (2011). Antioxidant and antidiabetic properties of condensed tannins in acetonic extract of selected raw and processed indigenous food ingredients from Kenya. Journal of Food Science, 76(4), 560-567. https:// doi.org/10.1111/j.1750-3841.2011.02116.x

Kusuma, I.W., Kuspradini, H., Arung, E.T., Aryani, F., Min, Y.H., Kim, J.S. and Kim, Y.U. (2011) Biological activity and phytochemical analysis of three Indonesian medicinal plants, Murraya koenigii, Syzygium polyanthum and Zingiber purpurea. Journal of Acupuncture and Meridian Studies, 4(1), 75-79. https://doi.org/10.1016/S2005-2901(11)60010 $-1$

Liu, S., Yu, Z., Zhu, H., Zhang, W. and Chen, Y. (2016). In vitro $\alpha$-glucosidase inhibitory activity of isolated fractions from water extract of Qingzhuan dark tea. BMC Complementary and Alternative Medicine, 16, 378. https://doi.org/10.1186/s12906-016-1361-0

Lund, B., Baird-Parker, A.C., Baird-Parker, T.C., Gould, G.W. and Gould, G.W. (2000). Microbiological Safety and Quality of Food. Berlin, Germany: Springer Science and Business Media.

Negukhula, S. (2010). Effects of brewing temperature and duration on quality of black tea (Camellia sinensis) and equal (50:50) combination of bush tea (Athrixia phylicoides DC.) and black tea. Limpopo, South Africa: University of Limpopo, MSc. Thesis.

Nguyen, Q.V. and Chuyen, H.V. (2020). Processing of herbal tea from roselle (Hibiscus sabdariffa L.): effects of drying temperature and brewing conditions on total soluble solid, phenolic content, antioxidant capacity and sensory quality. Beverages, 6(2), 1-11. https://doi.org/10.3390/beverages6010002

Oktavia, J.D. (2011). Pengoptimuman ekstraksi flavonoid daun salam (Syzygium polyanthum) dan analisis sidik jari dengan kromatografi lapis tipis. Bogor, Indonesia: Bogor Agricultural University, BSc. Thesis. [In Bahasa Indonesia]. 
Palmer, B., Jones, R.J., Wina, E. and Tangendjaja, B. (2000). The effect of sample drying conditions on estimates of condensed tannin and fibre content, dry matter digestibility, nitrogen digestibility and PEG binding of Calliandra calothyrsus. Animal Feed Science and Technology, 87(1-2), 29-40. https:// doi.org/10.1016/S0377-8401(00)00182-6

Perdana, F., Deden, W.S. and Rahmi, R.D. (2016). Penapisan fitokimia dan uji aktivitas antioksidan ekstrak metanol daun jambu bol (Syzygium malaccense (L.) Merr. and Perry), daun salam (Syzygium polyanthum (Wight.) Walpers), serta daun jamblang (Syzygium cumini (L.) Skeels) asal Arboretum Grut. Jurnal Farmako Bahari, 7(2), 2230. [In Bahasa Indonesia].

Ravikumar, C. (2014). Review on herbal teas. Journal of Pharmaceutical Sciences and Research, 6(5), 236238.

Ravindran, P.N. (2017). The Encyclopedia of Herbs and Spices. Cambridge, United Kingdom: CABI. https:// doi.org/10.1079/9781780643151.0000

Rodrigues, M.J., Oliveira, M., Neves, V., Ovelheiro, A., Pereira, C.A., Neng, N.R., Nogueira, J.M.F., Varela, J., Barreira, L. and Custódio, L. (2019). Coupling sea lavender (Limonium algarvense Erben) and green tea (Camellia sinensis (L.) Kuntze) to produce an innovative herbal beverage with enhanced enzymatic inhibitory properties. South African Journal of Botany, 120, 87-94. https://doi.org/10.1016/ j.sajb.2017.12.003

Roshanak, S., Rahimmalek, M. and Goli, S.A.H. (2016). Evaluation of seven different drying treatments in respect to total flavonoid, phenolic, vitamin $\mathrm{C}$ content, chlorophyll, antioxidant activity and color of green tea (Camellia sinensis or C. assamica) leaves. Journal of Food Science and Technology, 53 (1), 721-729. https://doi.org/10.1007/s13197-0152030-x

Rusaczonek, A., Swiderski, F. and Waszkiewicz-Robak, B. (2010). Antioxidant properties of tea and herbal infusions - a short report. Polish Journal of Food and Nutrition Sciences, 60(1), 33-35.

Saraswaty, V. (2012). Alpha glucosidase inhibitory activity from Syzigium sp. Jurnal Teknologi Indonesia, 33(1), 33-37.

Siregar, T.M. and Verena, V. (2019). Aktivitas inhibisi $\alpha$ -glukosidase minuman fungsional kayu secang (Caesalpinia sappan L.) dan ekstrak serai (Cymbopogon citratus), presented at Seminar Nasional Sains, Rekayasa and Teknologi (SNSRT), Tangerang, Indonesia, 2019. Tangerang, Indonesia: Faculty of Science and Technology, Universitas Pelita Harapan. [In Bahasa Indonesia].
Stone, H., Bleibaum, R.N. and Thomas, H.A. (2012). Sensory Evaluation Practices: Descriptive Analysis. USA: Elsevier. https://doi.org/10.1016/ B978-0-12-382086-0.00006-6

Sukmasari, S., Mohd, F.N., Doolaanea, A.A., Qader, O.A.J.A. and Rahman, M.N.A. (2018). Total phenolic content, flavonoid content, and antioxidant capacity of Syzygium cumini (L.) Skeels leaves grown in Wonosobo, Java, Indonesia and comparison against current findings of Syzygium cumini leaves and Syzygium polyanthum (Wight) Walp leaves. Journal of Pharmaceutical Sciences and Research, 10(1), 31-35.

Thamer, F.H., Dauqan, E.M., Naji, K.M. and Alshaibi, Y.M. (2018). The effect of drying temperature on the antioxidant activity of thyme extracts. Journal of Food Technology and Preservation, 2(3), 15-20.

Wahyuni, S. and Wita, W. (2017). Hypoglycemic and antioxidant effects of Syzygium polyanthum leaves extract on alloxan induced hyperglycemic Wistar rat. Bali Medical Journal, 3(3), 113-115. https:// doi.org/10.15562/bmj.v6i3.755

Wang, L., Liu, Y., Luo, Y., Huang, K. and Wu, Z. (2018). Quickly screening for potential $\alpha$ glucosidase inhibitors from guava leaves tea by bioaffinity ultrafiltration coupled with HPLC-ESITOF/MS method. Journal of Agricultural and Food Chemistry, 66(6), 1576-1582. https:// doi.org/10.1021/acs.jafc.7b05280

Widyawati, T., Yusoff, N., Asmawi, M. and Ahmad, M. (2015). Antihyperglycemic effect of methanol extract of Syzygium polyanthum (Wight) leaf in streptozotocin-induced diabetic rats. Nutrients, 7(9), 7764-7780. https://doi.org/10.3390/nu7095365

Wojdyło, A., Oszmiański, J. and Czemerys, R. (2007). Antioxidant activity and phenolic compounds in 32 selected herbs. Food Chemistry, 105(3), 940-949. https://doi.org/10.1016/j.foodchem.2007.04.038

$\mathrm{Xu}, \mathrm{P}$., Chen, L. and Wang, Y. (2019). Effect of storage time on antioxidant activity and inhibition on $\alpha$ amylase and $\alpha$-glucosidase of white tea. Food Science and Nutrition, 7(2), 636-644. https:// doi.org/10.1002/fsn3.899

Zhao, J., Deng, J.W., Chen, Y.W. and Li, S.P. (2013). Advanced phytochemical analysis of herbal tea in China. Journal of Chromatography A, 1313, 2-23. https://doi.org/10.1016/j.chroma.2013.07.039 